\title{
Pre-Service Teachers' Perceptions of Their Abilities to Teach Students with Special Needs by Integrating Technology in Their Classrooms
}

\author{
Abdulaziz S. Alawadh \\ Assistant Professor at the College of Basic Education in Kuwait \\ Naser GH. Ali. \\ Assistant Professor at the College of Basic Education in Kuwait \\ Faisal M. Almutairi \\ Assistant Professor at the College of Basic Education in Kuwait \\ Talal E. Alhuzimi \\ Assistant Professor at Department of Special Education, College of Education, King Saud University
}

\begin{abstract}
This inquiry is grounded in the theoretical framework of Technological Pedagogical Content Knowledge (TPACK). The study investigates pre-service special education teachers' self-efficacy beliefs, their perceptions of technology use for learning and teaching, their pedagogical approaches, and the challenges they face. A case study research design was employed to acquire quantitative data. Questionnaires were administered to a sample of 81 pre-service teachers from one teacher training college. The questionnaire also contained open-ended questions. Quantitative data was analysed using the statistical package for social sciences (SPSS) version 21 software while responses to the open-ended questions were thematically analysed. This study found that the pre-service teachers' use of technology may have developed over time and through the personal use of the devices in their classroom practices. Although the pre-service teachers had varied self-efficacy beliefs, they had positive attitudes towards the use of technology. Findings also suggest that the pre-service teachers lacked TPACK skills to use technology. Although most findings reinforce what is already known about the field, this study is unique as these results are new for Kuwait and possibly more widely for the Middle East. The study recommends that TPACK workshops may not only enhance better understanding of pre-service teachers' perceptions and beliefs about integrating technology to teach students with special needs but also provide increased support for them to improve their attitudes towards emerging technologies.
\end{abstract}

Keywords: Pre-service teachers, students with special needs, technology and integrating

DOI: $10.7176 / \mathrm{JEP} / 10-35-12$

Publication date: December $31^{\text {st }} 2019$

\section{Introduction}

This study examines pre-service teachers' self-efficacy beliefs and perceptions of technology when integrating technology for teaching students with special needs. The chosen context, within which this study takes place, is a teacher training college in Kuwait where pre-service teachers are being prepared for integrating technological tools and resources to support teaching and learning. Education reforms in this Gulf state have provided a perfect opportunity for the integration of new and emerging technologies (Almutairi, 2017; Alenezi, 2018; Safar \& AlKhezzi, 2013). A number of research studies have focused on pre-service or university teachers' perceptions, students' perceptions and integration of technology in general (e.g. Alfelaij, 2016; Aldhafeeri \& Alajmi, 2015; Al Behairi, 2016). However, a review of the literature, related to pre-service teachers' perceptions use of technologies to teach students with special education in Kuwaiti schools, suggests that there is very little research in these settings. This study addresses this gap by aiming to examine pre-service teachers' perceptions of their abilities to teach students with special needs by integrating technology in classrooms. The research question that guided this small scale study was:

What are pre-service teachers' perceptions of their abilities to teach students with special needs by integrating technology in classrooms?

\section{Literature review}

With the development of mobile technologies and the emergence of new pedagogical concepts, such as seamless learning, the use of technologies to facilitate learning has become a universal phenomenon. In such learning environments, it is claimed that there is the need to make a pedagogical shift from the outdated "instructionist and transmissionist views of learning" (Milrad et al., 2013, p. 106), where students are considered to be passive 
recipients of knowledge and not as active participants in learning (Montrieux et al. 2015). In order to effectively integrate and use technologies in special education classrooms, teachers require knowledge and skills as well as confidence in using these technologies. This is because teaching with technology is a complex process and involves the interaction between content, pedagogy and technology (Koehler \& Mishra, 2008).

\section{Pre-service teachers' perceptions and self-efficacy beliefs about technology use}

Meaningful integration of technology into learning and teaching is ill-designed, multifaceted, and cluttered (Redmond \& Lock, 2019). Teachers not only lack knowledge of technology but the complexity is further compounded by the diversity of learners and more specifically when the students need special education. A distinguishing factor in whether a teacher will use technology to teach students with special needs is their level of teacher self-efficacy (Corkett \& Benevides, 2015). Teacher self-efficacy is an important motivational construct that shapes teacher effectiveness in integrating technology in the classroom. Self-efficacy refers to a teacher's belief that he or she can teach or perform a certain action in order to achieve a given goal (Bandura, 2006; Browne, 2009). In other words, teachers' self-efficacy beliefs for technology shape their perceptions of their pedagogical practices and determine the level of teacher confidence and competence to engage with a task (Lemon \& Garvis, 2016). In terms of technology, a teacher's self-efficacy refers to a teacher's belief that he or she has the ability to work effectively with technology(Corkett \& Benevides, 2015). Self-efficacy has been identified as an influencing factor for teachers' technology integration practices (Ertmer \& Ottenbreit-Leftwich, 2010; Ottenbreit-Leftwich et al., 2010). Therefore, teachers who have a high sense of self-efficacy are not only more open to new ideas and more willing to try new pedagogical approaches (Leyser, et al., 2011) but also more resilient as they are likely to try harder to help all students to reach their potential (Pendergast, Garvis \& Keogh, 2011).

Technology in the form of apps for tablet computers (example iPads or android devices), smart phones and laptops are being increasingly used in classrooms. However, pre-service teacher's perceptions of technology and their self-efficacy beliefs in relation to technology may influence whether technology can be integrated into their lessons (Corkett \& Benevides, 2015). In the case of Kuwait, although teachers are required to obtain an International Computer Driving Licence (ICDL), they are either reluctant or lack the confidence to use these technologies (Al Sharija \& Watters, 2012). It is claimed that they need Technological pedagogical content knowledge (TPACK) to unpack the complexity of technology integration (Redmond \& Lock, 2019). Consequently, there are also claims that teacher education programmes should integrate the technological skills, pedagogical practices and perspectives of pre-service teachers in order to develop pre-service teachers' selfefficacy for teaching students with special needs (Corkett \& Benevides, 2015).

Bandura (2006) suggested that self-efficacy beliefs are most at play in early learning and that, once developed, teachers are resistant to change. This may be attributed to their negative perception about embedding technologies in their teaching (Alhashem \& Al-Jafar, 2015; Aldhafeeri et al., 2016; Alenezi, 2018). However, research suggests that pre-service teachers who participate in technology-enhanced teacher education programmes that include TPACK are less anxious about computers, and may have better pedagogical beliefs as well as self-efficacy toward integrating technology for teaching and learning (Voogt \& McKenney, 2017; Corkett \& Benevides, 2015). Furthermore, Ertmer (2005) suggested that the key elements that influence teachers' beliefs are personal experiences, vicarious experiences, and socio-cultural influences. Ottenbreit-Leftwich et al., (2010) claims that field experiences were critical for improving teachers' technology integration practices. This is particularly important for this study as TPACK workshops which are field experiences allow pre-service teachers to gain knowledge through vicarious experiences or through a second source of knowledge.

\section{Pre-service teachers' perceptions of lack of skills}

There is evidence to suggest that teachers' beliefs are influenced by their knowledge and skills. For instance, Ertmer et al. (2012) found that the key obstacles preventing teachers from using technology were their attitudes and beliefs towards technology, as well as their levels of knowledge and skills. Research from Kuwait reveals that most teachers lack basic digital-media and technological skills and pedagogical skills for using technologies (Alenezi, 2018; Al-Awidi \& Aldhafeeri, 2017). Furthermore, Kuwaiti teachers were also found to fear change, were hesitant in embedding technology in their curriculum practices and preferred traditional methods of teaching and teacher-centred approaches (Alfelaij, 2016). This suggests that technology necessarily does not fit the pedagogical approaches of these teachers in Kuwait. Research suggests that conservative beliefs and resistance to education overhaul is a big challenge when integrating technologies such as mobile devices for learning (AlHunaiyyan, Alhajri, \& Al-Sharhan, 2016). Equipping pre-service teachers with technology skills and knowledge especially TPACK, is a vital element of any teacher-training programme (Batane \& Ngwako, 2017).

\section{Theoretical framework}

Pre-service teachers are required to have knowledge of technology, innovative pedagogical approaches and content as well as the capacity for teaching students with special needs, when integrating new technologies (Anderson et 
al. 2017; Hutchings \& Quinney, 2015). Teachers, who lack knowledge or the skills to use technology, may not be able to integrate it successfully (Koehler et al., 2014). The TPACK model is considered important in the context of this study because "quality teaching" using technology "requires developing a nuanced understanding of the complex relationships between technology, content, and pedagogy, and using this understanding to develop appropriate, context-specific strategies and representations" (Mishra \& Koehler, 2006, p.1029). Therefore, this study examines teachers' beliefs about technology through the lens of the Technological Pedagogical Content Knowledge (TPACK) framework (Mishra \& Koehler, 2006).

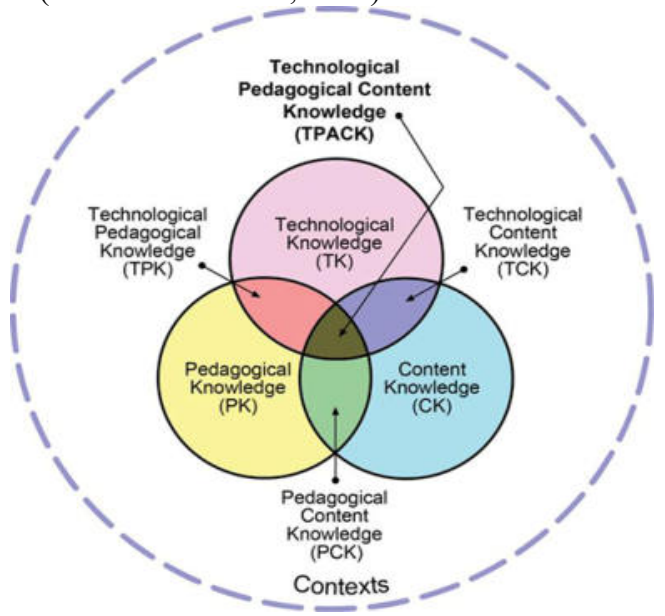

Figure 1: Technological Pedagogical Content Knowledge

(Adapted from Koehler \& Mishra, 2009)

The TPACK model offers a framework that educational institutions and educators can use to determine how to support pre-service special education teachers learn to make effective decisions regarding integrating technology into instruction (Anderson, Grifith \& Crawford, 2017; Lyublinskaya \& Tournaki, 2014). It provides a way to identify the diverse and distinctive types of knowledge that pre-service teachers need to develop in order to integrate technology effectively. Although most research have used TPACK as a theoretical framework to study teachers in general education settings (Koehler, Mishra \& Cain, 2013), there is a lack of research exploring its application with pre-service teachers in special education contexts (Anderson et al. 2017). Besides, there is no research from Kuwait that has ascertained how pre-service teachers' pedagogical and epistemological beliefs influence their decisions to integrate technology for teaching students with special needs in schools. This study also assumes that in the context of Kuwait, there is increasing pressure on teachers by policymakers to develop their own skills in using new learning technologies innovatively. This requires a significant paradigm shift in teachers' classroom practices.

\section{Research methodology}

A case study approach was used to understand pre-service teachers' perceptions of their abilities to integrate technology into the classroom. The objective was to understand how they had developed the abilities since they had not been exposed to the TPACK framework. The rationale for using a case study approach was to collect quantitative and rich qualitative data in relation to the case and to gain a better understanding of the research problem (Ponelis, 2015). A questionnaire was used to measure pre-service teachers' self-perceptions of their knowledge and skills for teaching with technology and their self-efficacy (confidence) for technology integration in classrooms which include students with special needs. The questionnaire comprised of the Technological Knowledge (TK), Technological Pedagogical Knowledge (TPK), and Technological Pedagogical and Content Knowledge (TPACK) domains of the TPACK framework (Schmidt eta al. 2009). It also included self-efficacy scales for teaching with technology (Wang et al. 2004).

\section{Data Analysis}

The quantitative data from the survey was analyzed with descriptive statistics to explore the subscales and demographic items. Since the intention was not to describe and make inferences about the population or to reach conclusions that extend beyond the immediate data, inferential statistics were not used. The use of a convergent parallel research design (Creswell, 2012) allowed utilizing quantitative analysis as part of the development of a case study (Yin, 2014). For this study, particular areas of interest in the quantitative analysis were comparisons of gender, area of specialisation, comfort with computers/mobile devices and comfort with using Internet/social media. 
Survey participants by gender

Table 2 shows that participants were equally distributed gender wise.

\begin{tabular}{lrr} 
Gender & N & Percent \\
\hline Male (all 3rd year Undergraduates) & 39 & $48 \%$ \\
Female (all 3rd year Undergraduates) & 42 & $52 \%$ \\
\hline
\end{tabular}

Table 1 Survey participants by gender

\section{Survey participants by area of specialisation}

\begin{tabular}{lc} 
Major/Specialisation Area & $\mathrm{N}$ \\
\hline Early Childhood & 0 \\
Elementary Education (General Classroom) & 3 \\
Elementary Special Education & 39 \\
Secondary Education (General Classroom) & 8 \\
Secondary Special Education & 31 \\
\hline Table 2 Survey participants by area of specialisation
\end{tabular}

Most of the participants were involved in teaching students with special needs (Elementary Special Education $\mathrm{N}=39$; Secondary Special Education $\mathrm{N}=31$ ).

Survey participants and their comfort with computers/mobile devices

\begin{tabular}{lcc} 
Comfort with computers/mobile devices & $\mathrm{N}$ & Percent \\
\hline Not at all comfortable & 2 & $2 \%$ \\
A little comfortable & 9 & $11 \%$ \\
Fairly comfortable & 32 & $40 \%$ \\
Very Comfortable & 38 & $47 \%$ \\
\hline
\end{tabular}

Table 3 Comfort with computers/mobile devices

Most participants were comfortable with using computer and mobile devices (Fairly 40\%; Very 47\%).

Survey participants and their comfort with using Internet/Social media

\begin{tabular}{lcc} 
Comfort with Internet/Social media & $\mathrm{N}$ & Percent \\
\hline Not at all comfortable & 1 & $1 \%$ \\
A little comfortable & 6 & $7 \%$ \\
Fairly comfortable & 25 & $31 \%$ \\
Very Comfortable & 49 & $60 \%$ \\
\hline
\end{tabular}

Table 4 Comfort with using Internet/social media.

Reliability statistics for survey subscales

Cronbach's alpha internal consistency coefficients for the sub-factors of the scale were found to be between 0.942 and 0.990 . The acceptable reliability for each scale was $>0.70$ which is indicative of higher indicate acceptable internal consistency and considered excellent (Taber, 2018).

\begin{tabular}{lcc} 
Subscale & Cronbach's Alpha & N of Items \\
\hline Technological Knowledge (TK) & 0.973 & 7 (1 to 7)) \\
Technological Pedagogical Knowledge (TPK) & 0.950 & 4 (8 to 11$)$ \\
Technological Pedagogical Content Knowledge (TPACK) & 0.942 & 3 (12 to 14) \\
Self-Efficacy for Technology Integration (SETI) & 0.990 & 10 (15 to 24) \\
\hline
\end{tabular}

Table 5 Cronbach alpha values 
Descriptive statistics for survey items

Descriptive statistics were used to determine teachers' self-efficacy on the overall scale of technology skills and knowledge, especially pedagogical and content knowledge.

Questionnaire items

1 I know how to solve my own technical problems.

2 I can learn technology easily.

3 I keep up with new and emerging technologies that can be used for teaching/learning.

4 I frequently use technology,

5 I know about a lot of different technologies.

Mean St Cou Sub-

I have the technical skills I need to use technology.

3.889

Dev. nt scale

4.296

$\begin{array}{lll}0.725 & 81 & \text { TK } \\ 0.679 & 81 & \text { TK }\end{array}$

$0.866 \quad 81 \quad$ TK

7 I have had sufficient opportunities to work with different 3.704 technologies.

8 I can make decisions and choose technologies that enhance the teaching approaches for a lesson.

9 My teacher preparation program has caused me to think more deeply about how technology could influence the teaching approaches I use in my classroom.

10 I am thinking critically about how to use technology in my classroom.

11 I can adapt the use of the technologies that I am learning about to different teaching activities.

12 I can teach lessons that appropriately combine content, technology, and teaching approaches.

13 I can provide leadership in helping others to coordinate the use of content, technologies, and teaching approaches at my school and/or district.

14 I can choose technologies that enhance the content for a lesson.

15 I feel confident that I understand educational technologies' capabilities well enough to maximize them in my classroom

16 I feel confident I can help students when they have difficulty with technology.

17 I feel confident that I have the skills necessary to use technology for instruction.

18 I feel confident in my ability to evaluate educational technology for teaching and learning.

19 feel confident that I can successfully teach relevant subject content with appropriate use of technology.

20 I feel confident I can provide individual feedback to students during technology use.

21 I feel confident I can be responsive to students' needs during technology use.

22 I feel confident about using technology for assignments and for assessing students.

23 I feel confident that I can motivate my students to participate in 4.247 technology-based projects.

24 I feel confident about using technology resources (such as Excel

$\begin{array}{llll}4.259 & 0.919 & 81 & \text { TK }\end{array}$

$\begin{array}{llll}3.753 & 0.830 & 81 & \text { TK }\end{array}$

$\begin{array}{llll}3.802 & 0.980 & 81 & \mathrm{TK}\end{array}$

$3.704 \quad 1.006 \quad 81 \quad$ TK

$3.975 \quad 0.894 \quad 81 \quad$ TPK

$\begin{array}{llll}4.531 & 0.853 \quad 81 \quad \text { TPK }\end{array}$

$\begin{array}{llll}4.321 & 0.849 & 81 & \text { TPK }\end{array}$

$\begin{array}{llll}4.284 & 0.675 & 81 & \text { TPK }\end{array}$

$\begin{array}{llll}4.432 & 0.611 & 81 & \text { TPACK }\end{array}$

$\begin{array}{llll}4.074 & 0.848 & 81 & \text { TPACK }\end{array}$

$\begin{array}{llll}4.123 & 0.812 & 81 & \text { TPACK }\end{array}$

$\begin{array}{llll}4.173 & 0.818 & 81 & \text { SETI }\end{array}$

$\begin{array}{llll}4.358 & 0.811 & 81 & \text { SETI }\end{array}$

$\begin{array}{llll}4.296 & 0.749 & 81 & \text { SETI }\end{array}$

$\begin{array}{llll}4.210 & 0.770 & 81 & \text { SETI }\end{array}$

$\begin{array}{llll}4.198 & 0.872 & 81 & \text { SETI }\end{array}$

$\begin{array}{llll}4.000 & 0.822 & 81 & \text { SETI }\end{array}$

$\begin{array}{llll}4.185 & 0.776 & 81 & \text { SETI }\end{array}$

4.086

$0.875 \quad 81$

SETI

$0.799 \quad 81 \quad$ SETI products to improve instructional practices.

\section{Table 6 Descriptive statistics}

\section{Results}

A close examination of the descriptive statistics (Table 6) makes it clear that teachers were able to use technology, although none of the pre-service teachers had any exposure to the TPACK framework. The mean score of preservice teachers for all items were high. Moving from these results, it can be said that the levels of pre-service teachers towards technology competencies and perception of technology integration self-efficacy is high. This is also consistent with other results from the descriptive statistics (Table 3 and 4) which shows that the pre-service teachers were either fairly comfortable or very comfortable with computers or mobile devices $(87 \%)$ and the 
Internet or social media (91\%).

Thematic analysis of the responses to the open-ended questions revealed five themes. The data was read and re-read and coded for the possible presence of any of the four technology-related TPACK domains (i.e., TK, TPK, TCK, or TPACK). The themes that emerged are tabulated (Table 8) discussed below.

Themes Inference

Lack of adequate skills Pre-service teachers had fair knowledge of use of technology but when integrating it in classrooms they had to rely on the experiences and practices of the colleagues and classmates.

Affordance Pre-service teachers considered that rapid technological development and its benefits or advantages of technology in education prompted them to use technology.

Constraints

Instructional strategy Pre-service teachers considered technology for its relevance to specific content while weighing the technology access issues, reliable instructional applications, college policies, lack of training, inadequate teacher preparation programmes and resource constraints

Pre-service teachers wanted to use technology for a specific instructional strategy; However, they were unable to combine pedagogy, content and technology in instructional strategy (in the learning process)

Expectations
Wanted more TPACK workshops to learn more about technology integration in classrooms for students with special needs. They also felt that the workshops would enable them to learn more about flipped classrooms, digital videos, social networking applications, collaborative learning and mobile learning as well as the TPACK framework.

Table 7 Themes

\section{Discussion of the findings}

In this study, the pre-service teachers believed that they had developed enhanced understanding of the role of technology in special education. The results of this study indicate that the pre-service teachers' self-efficacy on technology competency, and their beliefs in technology integration in future classroom instructions indicate that they have a good understanding of the role of technology in special education. These results paralleled those obtained in previous studies (for e.g. Lemon \& Garvis, 2016; Ertmer \& Ottenbreit-Leftwich, 2010; OttenbreitLeftwich et al., 2010) It is not enough for pre-service teachers to possess the requisite knowledge and skills to use technology, but also have self-efficacy beliefs in an effort to provide more engaging and effective instruction.

Although the pre-service teachers generally had confidence in using technology, based on their understanding of the affordances of new technologies, they also feel a sense of pressure to be able to teach with these tools. The pre-service teachers had to learn about technology integration from colleagues and therefore struggled with effective use of technology. Therefore, the findings of the current study suggest that teacher education programs cannot assume that just because their pre-service teachers are extensive users of technology, they will be confident in integrating technology in their lessons.

The results further suggest that the pre-service teachers had high levels of self-efficacy in using technology in a technical sense but in matters of pedagogical knowledge such as preparation, application, evaluation, supporting content learning, effective teaching strategies and performance assessment applications they lacked skills and knowledge. The reasons they attributed to this lack of knowledge were resource constraints, lack of training in effective technology integration and inadequate policies. This suggests that teacher educators and the college administrators have to support pre-service teachers in their learning to integrate technology, including modelling technology integration, providing both formal and informal learning opportunities to develop technological knowledge and skills, and helping pre-service teachers understand the link between technological knowledge, pedagogical knowledge, and content knowledge. Researchers have therefore recommended that preservice teachers can better understand technology integration through the development of TPACK (Redmond \& Lock, 2019) which should be an important element of teacher-training programmes (Batane \& Ngwako, 2017).

The results from this research echo some of the approaches that have been identified in the literature to be helpful to change teachers' beliefs about technology integration. For instance, Ertmer (2005) had suggested that pre-service teachers ought to engage in vicarious experiences by observing the college educators' technology integration practices. Such experiences can change their mind from a nonbeliever in technology integration to a strong advocate for technology use in education. This finding corroborates Ottenbreit-Leftwich et al. (2010) and Ertmer and Ottenbreit-Leftwich (2010) who claimed that field or vicarious experiences, for example workshops, are key for improving teachers' technology integration practices. The workshops provided an authentic experience for pre-service teachers and played a significant role in helping pre-service teachers develop stronger beliefs in the positive role of technology in education and enhance their self-efficacy on their technology integration practices.

Overall, the results of the current research has the potential to inform teacher preparation programs and in 
particular, suggests that a more advanced technology-focused curriculum paired with opportunity to implement new skills is warranted in order to continue to meet the needs of students with special needs. Based on the findings of this research, there is the need for TPACK workshops which the college and its educators should organise in order to foster pre-service teachers' abilities to integrate technology in special education classrooms. These workshops may allow pre-service teachers to build on their comfort with technology and the Internet and integrate the tools and apps effectively in their classrooms. Eventually, it would also help build on their self-efficacy.

\section{Implications}

The results of this study are crucial to stakeholders, for example the college administrators, educators and policy makers, to help them identify discordant practices which impede technology uptake by pre-service teachers. It would appeal to policy makers who can create enabling circumstances that would facilitate implementation of skills and knowledge that pre-service teachers obtained during the workshops. The policy makers could also use these ideas to develop adequate teacher preparation programmes. This study could also sensitise the teacher training college to make a conscious effort to infuse the TPACK framework as part of the curriculum so that its usage would be part of a holistic approach that promotes effective teaching.

\section{Conclusion and Recommendations}

The results point to a need to develop a systematic and comprehensive strategy toward technology implementation involving all stakeholders at the college level to ensure a smooth transition for pre-service teachers as they move from training to practice and to have technology use reinforced at all levels. There is a need for teacher educators to develop and implement programmes in ways that would allow prospective teachers to adapt technology into their classes, explore different technology options by understanding the importance of the TPACK concept. In other words, it is clear that there remains a need for more TPACK workshops and research in this area so that greater understanding can be developed of the skills and knowledge required for teachers for teaching students with special needs.

\section{References}

Al-Awidi, H., \& Aldhafeeri, F. (2017). Teachers' readiness to implement digital curriculum in Kuwaiti schools. Journal of Information Technology Education Research, 16(1), 105-126.

Al Behairi, N.H. (2016). Mobile learning: taking education to a new level. Sino-US English Teaching, 13(7), 505514.

Aldhafeeri, F.M., \& Alajmi, M.R., (2015). Towards excelled mobile learning implementation in Kuwait university: aspects and obstacles of use and non-use. Full Paper Proceeding BESSH-2016, 20, pp.5-19.

Aldhafeeri, F., Palaiologou, I., \& Folorunsho, A. (2016). Integration of digital technologies into play- based pedagogy in Kuwaiti early childhood education: teachers' views, attitudes and aptitudes. International Journal of Early Years Education, 24(3), 342-360.

Alenezi, E.G. (2018). An Investigation of Teachers' Beliefs and Attitudes Regarding the Use of Tablet Computers as a Pedagogical Tool in Teaching Practical Studies (Electricity and Electronics) inKuwaiti Intermediate Schools, University of Southampton, Doctoral Thesis, 320pp. https://eprints.soton.ac.uk/424740/

Alfelaij, B. (2016). Why integrating technology has been unsuccessful in Kuwait? An exploratory study. ELearning and Digital Media, 13(3-4), 126-139.

Alhashem, F, \& Al-jafar, A. (2015). Assessing teacher's integration of technology and literacy in elementary science classrooms in Kuwait. Asian Social Science, 11(18), 71-81.

Al-Hunaiyyan, A., Alhajri, R. A., \& Al-Sharhan, S. (2016). Perceptions and challenges of mobile learning in Kuwait. Journal of King Saud University Computer and Information Sciences, 1-11. http://dx.doi.org/10.1016/j.jksuci.2016.12.001

Almutairi, F, (2018). An investigation of the use of student-generated digital video to support students' engagement in their own learning. University of Southampton, Doctoral Thesis, 407pp. https://eprints.soton.ac.uk/419582/

Al-Sharija, M., \& Watters, J. J. (2012). Innovative leadership by school principals: embedding information communication and technology in Kuwaiti schools. Journal of International Education Research, 8(4), 425434.

Anderson, S., Grifith, R., \& Crawford. L. (2017). TPACK in special education: Preservice teacher decision making while integrating iPads into instruction. Contemporary Issues in Technology and Teacher Education, 17(1), 97-127.

Bandura, A. (2006). Guide for constructing self-efficacy scales. In F. Pajares \& T. Urdan (Eds.), Adolescence and education: Vol. 4. Self-efficacy beliefs of adolescents (pp. 307-338). Greenwich, CT: Information Age.

Batane, T., \& Ngwako, A. (2017). Technology use by pre-service teachers during teaching practice: Are new teachers embracing technology right away in their first teaching experience? Australasian Journal of 
Educational Technology, 33(1), 48-61.

Browne, J. (2009). Assessing pre-service teachers' attitudes and skills with the technology integration confidence scale. Computers in Schools, 26, 4-20. http://dx.doi.org/10.1080/07380560802688240

Corkett, J.K., \& Benevides, T. (2015). Pre-service Teachers' Perceptions of Technology and Multiliteracy Within the Inclusive Classroom, International Journal of Psychology and Educational Studies, 2 (2), 35-46.

Creswell, J.W. (2012). Educational research: Planning, conducting, and evaluating quantitative and qualitative research (4th edn). Boston, MA: Pearson Education, Inc.

Ertmer, P. A., Ottenbreit-Leftwich, A. T., Sadik, O., Sendurur, E., \& Sendurur, P. (2012). Teacher beliefs and technology integration practices: a critical relationship. Computers \& Education, 59(2), 423-435.

Ertmer, P. A. (2005). Teacher pedagogical beliefs: The final frontier in our quest for technology integration? Educational Technology Research and Development, 53(4), 25-39.

Ertmer, P. A., \& Ottenbreit-Leftwich, A. (2010). Teacher technology change: How knowledge, confidence, beliefs, and culture intersect. Journal of Research on Technology in Education, 42, 255-284.

Hutchings, M., \& Quinney, A. (2015). The flipped classroom, disruptive pedagogies, enabling technologies and wicked problems: responding to 'the bomb in the basement. The Electronic Journal of e-Learning, 13(2), 106-119.

Koehler, M., \& Mishra, P. (2008). Introducing TPCK. In AACTE Committee on Innovation and Technology (Eds.), The handbook of technological pedagogical Content knowledge (TPCK) for educators (pp. 3-29). New York, NY: AmericanAssociation of Colleges of Teacher Education and Routledge.

Koehler, M. J., \& Mishra, P. (2009). What is technological pedagogical content knowledge? Contemporary Issues in Technology and Teacher Education (CITE Journal), 9(1), 60-70.

Koehler, M., Mishra, P., Kereluik, K., Shin, T., \& Graham, C. (2014). The technological pedagogical content knowledge framework. In: J. M. Spector, M. D. Merrill, J. Elen \& M. J. Bishop (Eds.) Handbook of research on educational communications and technology. New York: Springer. (pp. 101-111) http://dx.doi.org/10.1007/978-1-4614-3185-5_9

Lemon, N., \& Garvis, S. (2016) Pre-service teacher self-efficacy in digital technology, Teachers and Teaching, 22(3), 387-408 http://dx.doi.org/10.1080/13540602.2015.1058594

Leyser, Y., Zeiger, T., \& Romi, S. (2011). Changes in self-efficacy of prospective special and general education teachers: implication for inclusive education. International Journal of Disability, Development and Education, 58(3), 241-255. http://dx.doi.org/10.1080/1034912X.2011.598397

Lyublinksaya, I., \& Tournaki, N. (2014). A study of special education teachers' TPACK development in mathematics and science through assessment of lesson plans. Journal of Technology and Teacher Education, 22(4), 449-470

Milrad, M., Wong, L.-H., Sharples, M., Hwang, G.-J., Looi, C.-K., \& Ogata, H. (2013). Seamless learning: an international perspective on next generation technology enhanced learning. In: Z. L. Berge \& L. Y. Muilenburg (Eds.) Handbook of mobile learning. New York: Routledge (pp 95-108).

Mishra, P., \& Koehler, M. J. (2006). Technological pedagogical content knowledge: a framework for teacher knowledge. Teachers College Record, 108 (6), 1017-1054.

Montrieux H, Vanderlinde R, Schellens T, \& De Marez L (2015). Teaching and learning with mobile technology: a qualitative explorative study about the introduction of tablet devices in secondary education. PLoS ONE 10(12): e0144008. https://dx.doi.org/10.1371/journal.pone.0144008

Ottenbreit-Leftwich, A. T., Glazewski, K. D., Newby, T. J., \& Ertmer, P. A. (2010). Teacher value beliefs associated with using technology: Addressing professional and student needs. Computers \& Education, 55, 1321-1335. http://dx.doi.org/10.1016/j.compedu.2010.06.002

Pendergast, D., Garvis, S., \& Keogh, J. (2011). Pre-Service Student-Teacher Self-efficacy Beliefs: An Insight Into the Making of Teachers, Australian Journal of Teacher Education, 36(12), 46-57.

Ponelis, S.R. (2015). Using interpretive qualitative case studies for exploratory research in doctoral studies: A case of Information Systems research in small and medium enterprises. International Journal of Doctoral Studies, $10,535-550$.

Redmond, P., \& Lock, J. (2019) Secondary pre-service teachers' perceptions of technological pedagogical content knowledge (TPACK): What do they really think? Australasian Journal of Educational Technology, 35(3), 45-54.

Safar, A., \& AlKhezzi, F. (2013). Beyond computer literacy: technology integration and curriculum transformation. College Student Journal, 47(4), 614-626.

Schmidt, D. A., Baran, E., Thompson, A. D., Mishra, P., Koehler, M. J., \& Shin, T. S. (2009). Technological pedagogical content knowledge (TPACK): The Development and validation of an assessment instrument for preservice teachers. Journal of Research on Technology in Education, 42(2), 123-149.

Taber, K.S. (2018). The Use of Cronbach's Alpha When Developing and Reporting Research Instruments in Science Education, Research in Science Education, 48(6), 1273-1296 https://doi.org/10.1007/s11165-016- 
$9602-2$

Voogt, J., \& McKenney, S. (2017) TPACK in teacher education: are we preparing teachers to use technology for early literacy?, Technology, Pedagogy and Education, 26(1), 69-83 http://dx.doi.org/10.1080/1475939X.2016.1174730

Wang, L., Ertmer, P. A., \& Newby, T. J. (2004). Increasing preservice teachers' selfefficacy beliefs for technology integration. Journal of Research on Technology in Education, 36(3), 231-250.

Yin, R.K. (2014). Case Study Research: Design and Methods ( $5^{\text {th }}$ edn). Thousand Oaks, CA: Sage. 